\title{
Sweet potato Weevil (Cylas puncticollis) Boheman Infestation: Cultivar Differences and the Effects of Mulching
}

\author{
A. Mansaray ${ }^{1}$, A. J. Sundufu ${ }^{2, *}$, M. T. Moseray ${ }^{1}$ and S. N. Fomba ${ }^{1}$ \\ ${ }^{I}$ Sierra Leone Agricultural Research Institute, Njala, Sierra Leone; ${ }^{2}$ Mercy Hospital Research Laboratory, Bo, Sierra \\ Leone
}

\begin{abstract}
The effects of infestation by the sweet potato weevil, Cylas puncticollis Bohemen, on yield in 3 sweet potato cultivars, in relation to different mulching levels were compared. The experiment was laid out in a randomized complete split plot design at three levels. It consisted of a main plot factor, the three sweet potato cultivars (slipot 2, 3 and 4) with mulching at three levels $(0,1,3$ and 5 t/ha) as sub plot. The factors were replicated thrice. The results of the studies revealed that increase in mulching level resulted in significantly decreased infestation of sweet potato weevil and higher root yield. Mulching at the rate of $5 \mathrm{t} / \mathrm{ha}$ recorded the least infestation $(12.13 \%$ for the year $2012 ; 13.32 \%$ for the year $2013)$ followed by $3 t /$ ha $(17.86 \%$ for the year $2012 ; 21.24 \%$ for the year 2013$), 1 t /$ ha $(25.18 \%$ for the year $2012 ; 29.49 \%$ for the year 2013) whilst the unmulched plot recorded the highest (35.75\% for the year $2012 ; 41.30 \%$ for the year 2013). Root yield was the highest with mulching at the rate of $5 \mathrm{t} / \mathrm{ha}(6242.42 \mathrm{Kg} / \mathrm{ha}$ for the year $2012 ; 4828.45 \mathrm{Kg} / \mathrm{ha}$ for the year 2013) followed by $3 \mathrm{t} / \mathrm{ha}(5863.64 \mathrm{Kg} / \mathrm{ha}$ for the year $2012 ; 4883.82 \mathrm{Kg} / \mathrm{ha}$ for the year 2013$), 1 \mathrm{t} / \mathrm{ha}(4580.81 \mathrm{Kg} / \mathrm{ha}$ for the year $2012 ; 3818.18 \mathrm{Kg} / \mathrm{ha}$ for the year 2013) whilst the unmulched plot recorded the highest $(4202.03 \mathrm{Kg} / \mathrm{ha}$ for the year $2012 ; 3489.89 \mathrm{Kg} / \mathrm{ha}$ for the year 2013). Significant negative correlation $(r=-0.91, p=0.0001)$ was observed between weevil root damage and root dry matter. Only two cultivars, Slipot 3 and Slipot 4 were observed to be less susceptible to the sweetpoto weevil. Thus, using mulch cover at the rate of 3-5t/ha in a field planted with slipot 3 or slipot 4 will increase yield, while at same time reduce sweet potato weevil infestation.
\end{abstract}

Keywords: Cylas puncticollis, dry matter, mulching, percentage damage, sweet potato, yield.

\section{INTRODUCTION}

In Africa, the sweet potato weevils Cylas puncticollis Boheman and Cylas brunnheus Fabricus are the major sweet potato (Ipomoea batatas [L.] Lam) production constraint. Cylas spp can damage every harvestable part of the plant with devastating consequences for poor farmers leading to low income and reduced food security $[1,2]$.

Sweet potato is the third most important crop in Sierra Leone after rice and cassava [3, 4], and a staple food for a large proportion of the population in many parts of subSaharan Africa [5, 6].

Damage to sweet potato by $C$. puncticollis is particularly severe during the dries; as the pest which cannot dig but gain access to sweet potato roots through cracks that appears in the soil as the soil dries out under moisture stress. Thus, sustainable management of this pest will boost sweet potato production and impact positively on the livelihood of millions of poor farmers across sub-Saharan African. Host plant resistance is one of the strategies that had been adopted in the management of this pest. However, progress in breeding varieties with resistance to C. puncticollis and C. brunneus that is of dynamic rather than escape has been slow largely due to the scarcity of varieties with significant level of

*Address correspondence to this author at the Mercy Hospital Research Laboratory, BO City, Sierra Leone; Tel: +232 76701269;

E-mail: jasundufu@gmail.com resistance $[7,8]$. The application of crop residue (mulch) has also been reported to improve soil water supply to crops through reduced runoff, soil evaporation, increased infiltration and water storage thereby reducing cracks in the soil [9]. In this experiment, we investigate the appropriate mulching rate that reduces weevil infestation in the field and the sweet potato cultivar that is less susceptible to Cylas spp under natural infestation.

\section{MATERIALS AND METHODS}

\section{Experimental Site}

The experiments were conducted at Njala Agricultural Research Centre Experimental site (Latitude $8^{0} 06^{\prime} \mathrm{N}$, Longitude $12^{\circ} 06^{\prime} \mathrm{W}$ and Altitude $50 \mathrm{~m}$ above sea level), Njala, Sierra Leone during two cropping seasons (2012 and 2013). There are two distinct seasons, the wet season (MayOctober) and the dry season (November -April). The mean annual rainfall at Njala is $2,525 \mathrm{~mm}$; mean monthly maximum air temperature ranged from $29^{\circ} \mathrm{C}$ to $23^{\circ} \mathrm{C}$. Relative humidity is very high often close to $100 \%$ for greater part of the day and night especially during the rainy season. During the dry season, potential evapo-transpiration exceeds rainfall while during the rainy season precipitation exceeds evapotranspiration. The predominant vegetation at Njala is secondary bush and the soils belong to the Njala series (Orthoxic palehumult). Textures are usually gravelly clay loam in the surface and gravelly clay loam to gravelly clay in the sub-soil. The soils are low in soil moisture and have a low 
nutrient status and are slightly acidic with $\mathrm{pH}$ ranging from 5.5 to 6.0 . The monthly rainfall during the two cropping season is shown in Table 1.

Table 1. Monthly rainfall during the two cropping seasons.

\begin{tabular}{|c|c|c|}
\hline \multirow{2}{*}{ Month } & \multicolumn{2}{|c|}{ Rainfall (mm) } \\
\cline { 2 - 3 } & $\mathbf{2 0 1 2}$ & $\mathbf{2 0 1 3}$ \\
\hline \hline September & 385.0 & 493.00 \\
\hline October & 320.0 & 285.50 \\
\hline November & 188.0 & 15.00 \\
\hline December & 7.5 & 0.00 \\
\hline
\end{tabular}

\section{Experimental Material, Design and Field Management}

The treatments consist of three sweet potato cultivars namely; (slipot 2, 3 and 4) with mulching, using freshly harvested, dried chopped up aerial parts of elephant grass (Panicum maximum), at three levels (0, 1, 3 and 5t/ha) as sub plot. The $(3 \times 3)$ factorial combinations were laid out in a split plot design replicated thrice. The plot size was $14.4 \mathrm{~m}^{2}$ with each plot having four ridges $1 \mathrm{~m}$ apart and $3.6 \mathrm{~m}$ long. Diseases and weevil free fresh vine tips ca. $30 \mathrm{~cm}$ and carrying four to five nodes were planted with two to three nodes under ground at $45^{\circ}$ to the ridge top in holes prepared by using sharp pointed sticks of about $4 \mathrm{~cm}$ diameter. Planting was done on the $10^{\text {th }}$ September, during the 2012 cropping season and on the $14^{\text {th }}$ September, during the 2013 cropping season. The mulching material was applied immediately after sprouting and was kept till after harvest. Weeding was done as and when necessary. At harvest, the plant stands at either end of the ridges in each plot were discarded. The two middle rows in each plot were harvested.

\section{Data Collection and Analysis}

Data collected at the time of harvesting included, percentage infestation and percentage damage.

\section{Number of Tubers with $C$. puncticollis Infestation}

A root was considered infested if it bores characteristics dark scarred spots on the surface of the root a typical symptom of weevil penetration and feeding, Those root lacking any surface damage were considered to be uninfested [7]. Percentage tuber infestation was expressed as the total number of infested roots per plot divided by the total number of roots harvested (including both infested and uninfested) multiplied by 100 .

\section{Determination of Dry Matter Content of Tubers with C. puncticollis Infestation}

The storage root tubers from the surviving plants on each ridge were carefully dug up, collected and weighed to obtain the overall weight per plot. Percentage dry matter content was determined within 24 hours of harvest. Fresh root tuber of each cultivar was sliced into pieces and $100 \mathrm{~g}$ was dried in an oven at $80^{\circ} \mathrm{C}$ for 24 hours until a constant weight was achieved. Percentage dry matter content was calculated using the formula:

$$
I=\frac{a}{a+b} \times 100
$$

Where;

$\mathrm{I}=$ percentage dry matter content

$\mathrm{a}=$ final weight of infested tubers - initial weight of infested tuber

$b=($ final weight of infested tubers - initial weight of infested tubers) + (final weight of uninfested

tubers - initial weight of uninfested tubers)

\section{Data Analysis}

Data collected during the two seasons were subjected to two-way ANOVA and means were separated using the student Newman-Keuls Tests (SNK), at 0.05 level of significance [10]. Also Pearson correlations was performed to establish the relationships between sweet potato weevil incidence and yield and also between percentage dry matter content and number of tuber damage by Cylas.

\section{RESULTS}

\section{Cylas Puncticollis Tuber Infestation}

Analysis using ANOVA reveals significant differences $(\mathrm{P}<0.05)$ in $C$. puncticollis tuber infestation across sweet potato cultivar with slipot 2 recording the highest tuber infestation followed by Slipot 4 whilst Slipot 3 recorded the least tuber infestation across both seasons (Table 2). Regarding mulching levels, the mulched plots registered a significantly $(\mathrm{P}<0.05)$ lower tuber infestation compared to the unmulched plot. Mulching at the rate of $5 \mathrm{t} / \mathrm{ha}$ recorded the least infestation $(12.13 \%$ for the year $2012 ; 13.32 \%$ for the year 2013) followed by 3t/ha (17.86\% for the year 2012; $21.24 \%$ for the year 2013$), 1 \mathrm{t} /$ ha $(25.18 \%$ for the year 2012 ; $29.49 \%$ for the year 2013) whilst the unmulched plot recorded the highest $(35.75 \%$ for the year $2012 ; 41.30 \%$ for the year 2013) (Table 2). In general, sweet potato tuber infestation as a result of $C$. puncticollis was higher during 2013 cropping season (26.31\%) compared to 2012 cropping season $(22.73 \%)$. Furthermore, the interaction between sweet potato cultivar and mulching levels with respect to weevil infestation was not significant $(\mathrm{P}>0.05)$.

\section{Yield}

Relating to yield, significant differences $(\mathrm{P}<0.05)$ were observed with respect to cropping season with 2012 cropping season recording a significantly higher mean yield $(5222.23 \mathrm{Kg} / \mathrm{ha})$ compared to the mean yield (4255.09 $\mathrm{Kg} / \mathrm{ha}$ ) of 2013 cropping season (Table 3). Across cultivar, significant differences $(\mathrm{P}<0.05)$ were reported with slipot 4 registering the highest yield followed by slipot 2 whilst slipot 3 recorded the least across both cropping season.

With respect to mulching level, higher yield was observed in the mulched plots compared to the unmulched plots. Yield was observed to increase significantly $(\mathrm{P}<0.05)$ with increase in mulching level. Mulching at the rate of $5 \mathrm{t} / \mathrm{ha}$ recorded the highest root yield $(6242.42 \mathrm{Kg} / \mathrm{ha}$ for the year 
Table 2. Cylas puncticollis tuber infestation with respect to cultivar and mulching levels during 2012 and 2013 cropping season.

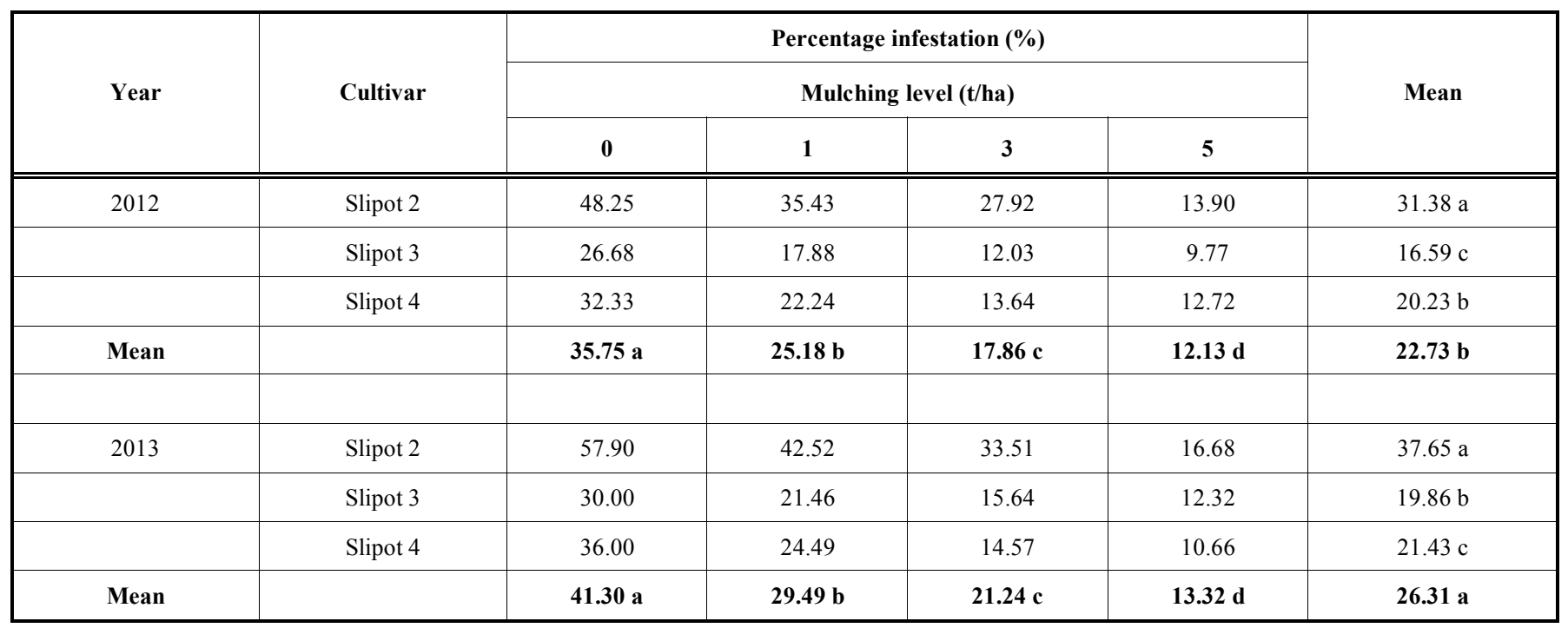

With regards mulching levels, means in row with the same letter are not significantly different at $\mathrm{P}>0.05$ (SNK); with regards year (last column), means in the same column with the same letter are not significantly different at $\mathrm{P}>0.05$.

Table 3. Yield with respect cultivar and mulching level during 2012 and 2013 cropping season.

\begin{tabular}{|c|c|c|c|c|c|c|}
\hline Year & Cultivar & \multicolumn{4}{|c|}{ Tuber yield (kg/ha) } & Mean \\
\hline \multirow[t]{2}{*}{2012} & Slipot 2 & 3121.21 & 5000.00 & 5909.09 & 6515.15 & $5136.36 \mathrm{~b}$ \\
\hline & Slipot 3 & 4772.73 & 3727.27 & 5257.58 & 4681.82 & $4609.85 \mathrm{c}$ \\
\hline Mean & & $4202.03 \mathrm{~d}$ & $4580.81 \mathrm{c}$ & 5863.64 b & $6242.42 \mathrm{a}$ & 5222.23 a \\
\hline \multirow[t]{2}{*}{2013} & Slipot 2 & 2575.76 & 4166.66 & 4924.24 & 5560.61 & $4306.82 \mathrm{~b}$ \\
\hline & Slipot 3 & 3969.69 & 3106.07 & 4378.75 & 3909.09 & $3840.90 \mathrm{c}$ \\
\hline
\end{tabular}

With regards mulching levels, means in row with the same letter are not significantly different at $\mathrm{P}>0.05$ (SNK); with regards year (last column), means in the same column with the same letter are not significantly different at $\mathrm{P}>0.05$.

$2012 ; 4828.45 \mathrm{Kg} /$ ha for the year 2013 ) followed by $3 \mathrm{t} / \mathrm{ha}$ $(5863.64 \mathrm{Kg} / \mathrm{ha}$ for the year $2012 ; 4883.82 \mathrm{Kg} / \mathrm{ha}$ for the year $2013), 1 \mathrm{t} / \mathrm{ha}(4580.81 \mathrm{Kg} / \mathrm{ha}$ for the year $2012 ; 3818.18 \mathrm{Kg} / \mathrm{ha}$ for the year 2013) whilst the unmulched plot recorded the highest $(4202.03 \mathrm{Kg} /$ ha for the year $2012 ; 3489.89 \mathrm{Kg} /$ ha for the year 2013) (Table 3). Furthermore, a non-significant weak negative correlation $(\mathrm{r}=-0.20, \mathrm{P}=0.79)$ was observed between percentage damage and yield. In addition, the interaction between sweet potato cultivar and mulching level with respect to yield was not significant $(\mathrm{P}>0.05)$ across the two cropping seasons.

\section{Percentage Dry Matter}

Percentage dry matter was also observed to vary significantly $(\mathrm{P}<0.05)$ across sweet potato cultivar with slipot 4 recording the highest dry matter content followed by slipot 3 while slipot 2 recorded the least across the two cropping season (Table 4). On the other hand, no significant differences $(\mathrm{P}>0.05)$ were recorded in percentage dry matter across mulching levels during the two cropping seasons. Furthermore, a strong significant negative correlation $(\mathrm{r}=-0.91$, $\mathrm{P}=0.0001$ ) was recorded between dry matter content and the number of tuber damaged by the sweet potato weevil.

\section{DISCUSSION}

Management practices such as mulching, and cultivar selection influences sweet potato weevil population and sweet potato damage in the field. The present study shows significant differences in C. puncticollis damage with respect to the nature of the cultivar and mulching level. The nature of the 
Table 4. Percentage dry matters content with respect to cultivar and mulching level during 2012 and 2013 cropping season.

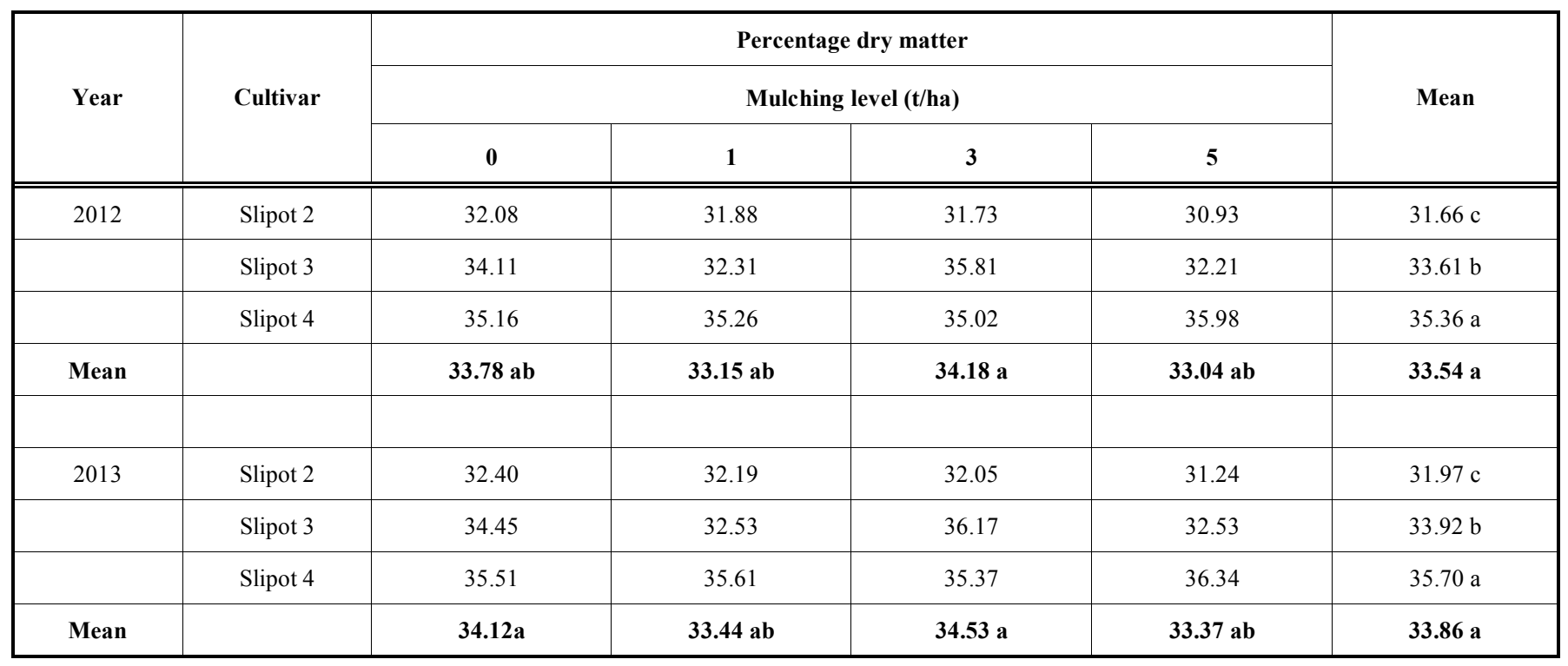

With regards mulching levels, means in row with the same letter are not significantly different at $\mathrm{P}>0.05$ (SNK); with regards year (last column), means in the same column with the same letter are not significantly different at $\mathrm{P}>0.05$.

cultivar used had influence on the damage of $C$. puncticollis; as such Slipots 3 and 4 incurred the least damage, respectively, compared slipot 2 . The reason for the above observation could be related to differences in rooting habit among the cultivars used. Slipot 3 is known to be a deep- rooted cultivar; which makes it difficult for the sweet potato weevil to access even under low moisture condition. The sweet potato weevil Cylas spp cannot dig but, gain access to exposed roots through cracks in the soil, as such, deep-rooting can act as an escape mechanism [7, 8]. Slipot 4 on the other hand, has a high dry matter content coupled with its hard peel makes it difficult for C. puncticollis to puncture and hence confers some form of resistance. This result corroborates with the findings of [11]. These authors reported that Cylas spp can actively differentiate between sweet potato parts or have preference for some varieties over others. The results also conform to the findings of [12] who reported strong evidence of resistance among dry-fleshed cultivars. In addition, reduced feeding and ovipostion was also attributed to genetic variation among cultivars [13]. In general, sweet potato weevil tuber damage was higher during 2013 cropping season compared to 2012 cropping season. The reason for the above observation could probably be related to the differences in rainfall pattern between the two cropping season as more rainfall was recorded during 2012 cropping season compared to 2013 cropping season (Table 1).

Relating to mulching levels; sweet potato weevil tuber damage was generally low in mulched plots during the two cropping seasons compared to the unmulched plots; which translated into fewer number of tubers damaged. This could be due to the fact that the mulch material helps to reduce evapotranspiration and increase soil water retention thereby preventing cracks in the soil that facilitates attack by the sweet potato weevil $[7,9]$. According to Mulumba and Lal [14], applying mulch even at low rates can have a strong impact on the water available capacity of the soil. The mulching material also provides a favourable environment for the natural enemies of C. puncticollis thereby reducing their incidence and severity [15].

The result also suggests significant differences in tuber yield across mulching regime with mulched plots recording significantly higher yield compared to the unmulched plots. This result concords with the finding of Walworth and Carling [16] who reported that mulching increase crop yield by promoting early tuber initiation. Stone et al. [17] also reported that in Northern Alabama, the highest yield of beauregard sweet potato was produced from kill-cover crop treatments of crimson or hairy vetch. The increase in yield with mulching could be attributed to the fact that the mulch material reduces soil temperature which affects rootset and tuber bulking [18]. Also, significant variation in yield was recorded across sweet potato cultivars during the two cropping seasons. Lower damage occurred during the second planting season, with more rains, when soil cracks were minimized. Absence of cracks denies the weevil access to the roots.

The result also indicates a strong significant negative correlation between dry matter content and the number of tuber damaged by $C$. puncticolli. The above observation indicates that increase dry matter content of a cultivar results into a decrease in susceptibility of that cultivar to C. puncticollis as in the case for slipot 4 . This result confirms with the findings of Antiaobong and Bassey [19]. These authors stated that high dry matter content is among one of the important factors for the selection of sweet potato and serves as indicator of adaptability of the crop to local conditions.

\section{CONCLUSION}

The results from this study suggests that slipot 3 and 4 are less susceptible to weevil infestation in the field and that mulching increases sweet potato yield and reduces sweeetpotato weevil infestation in the field. 


\section{CONFLICT OF INTEREST}

The authors confirm that this article content has no conflict of interest.

\section{ACKNOWLEDGEMENTS}

This work was supported with funds from the Sierra Leone Agricultural Research Institute.

\section{REFERENCES}

[1] Nottingham SF, Kays SJ. Sweet potato weevil control. In: Malagamba, PJ; Ed. Proceedings of $1^{\text {st }}$ International Conference on Sweet Potato Food and Health for the Future. Acta Horti 2002; 583:155-61.

[2] Magira P. Evaluating sweet potato clones for resistance to the African sweet potato weevils (Cylas puncticollis) Boheman and Cylas brunneus (Fab.) (Coleoptera: Apionidae). MSc thesis: Makerere University 2003; pp. 26-30.

[3] SSL (Statistics Sierra Leone) 2010. Annual Economic Survey: Economic Statistics 2010; Division 2.

[4] IMF (International Monetary Fund). Sierra Leone: Poverty Reduction Strategy Paper-Progress Report 2008-2010. IMF Country Report 2011; pp. 11/95.

[5] Muyinza H, Talwana HL, Mwanga ROM, Stevenson PC. Sweet potato weevil (Cylas spp.) resistance in African sweet potato germplasm. Int J Pest Manage 2012; 58 (1): 73-81.

[6] Rukarwa RJ, Prentice K, Ormachea M, et al. Evaluation of Bioassays for testing Bt sweet potato events against sweet potato weevils. Afr Crop Sci J 2013; 21 (3): 235-44.

[7] Stathers TE, Rees D, Kabi S, et al. Sweet potato infestation by Cylas spp. in East Africa: I. Cultivar differences in field infestation and the role of plant factors. Int J Pest Manage 2003a; 49(2): 13140.

[8] Stathers TE, Rees D, Nyango A, et al. Sweet potato infestation in East Africa: II. Investigating the role of root factors. Int J Pest Manage 2003b; 49:141-50.
[9] Erenstein O. Crop residue mulching in tropical and semitropical countries. An evaluation of residue availability and the technological implications. Soil Tillage Res 2002; 67: 115-33.

[10] SAS Institute. The SAS system for windows, Release 8.1.Cary: NU, USA, 2001.

[11] Muyinza H, Stevenson PC, Talwana H, Hall DR, Dudley IF, Mwanga ROM. Root chemicals could offer opportunities for breeding for sweet potato resistance to the weevil Cylas puncticollis Boheman (Coleoptera: Apionidae). London: Royal Soc Chem Pub 2010; 49-57.

[12] Jackson DM, Bohac JR. Improved dry-fleshed sweet potato genotypes resistant to insect pests. J Econ Entomol 2006; 99:1877-83.

[13] Mao LX, Story RN, Hammond AM, Labonte DR. Effect of sweet potato genotype, storage time and production site on feeding and oviposition behavior of the sweet potato weevil, Cylas formicarius (Coleoptera: Apoinidae). Flor Entomol 2001; 84: 259-64.

[14] Mulumba LN, Lal R. Mulching effect on selected soil physical properties. Soil Tilllage Res 2008; 98: 106-11.

[15] Tillaman GH, Schomberg S, Phatak B, Mullinix S, Lachnicht P, Olson D. Influence of cover crops on insect pests and predator in conservation tillage cotton. J Econ Entomol 2004; 97: 121.

[16] Walworth JL, Carling DE. Tuber initiation and development in irrigated and non-irrigated potatoes. Am J Potato Res 2002; 79: 387-95.

[17] Stone AJ, Kemble R, Raper, L, Fields D. Development of a more sustainable sweet potato production system for Alabama. In: Proceedings of the National Sweet potato Collaborators Group Meeting, Little Rock AR. 5-6 February 2005; pp. 7-8.

[18] Ossom EM, Pace PF, Rhykerd RL, Rhykerd CL. Effect of mulch on weed infestation, soil temperature, nutrient concentration and tuber yield in Ipomoea batatas in Papua New Guinea. Trop Agricul 2001; 78: 144-51.

[19] Antiaobong EE, Bassey EE. Constraint and prospects of sweet potato (Ipomoea batatas (L) Lam) production in the humid environment of Southern Nigeria. Proceedings of the $2^{\text {nd }}$ African Regional Conference on Sustainable Development, held at the governor's office annex: Uyo, Nigeria 2008; pp. 68-72.

Received: November 05, 2014

Revised: December 18, 2014

Accepted: December 30, 2014

(C) Mansaray et al.; Licensee Bentham Open.

This is an open access article licensed under the terms of the Creative Commons Attribution Non-Commercial License (http://creativecommons.org/licenses/by-nc/3.0/) which permits unrestricted, non-commercial use, distribution and reproduction in any medium, provided the work is properly cited. 